\title{
Effects of use and mineral supply on the botanical composition and yield of old grassland on heavy-clay soil
}

W. Th. Elberse ${ }^{1}$ J. P. van den Bergh ${ }^{1}$ and J. G. P. Dirven ${ }^{2}$

${ }^{1}$ Centre for Agrobiological Research (CABO), P.O. Box 14, 6700 AA Wageningen, Netherlands

${ }_{2}$ Department of Field Crops and Grassland Science, Agricultural University, Wageningen, Netherlands

Received 1 March 1982; accepted 28 July 1982

Key-words: botanical composition, permanent grassland, hayfield, pasture, dry matter production, fertilizers, population dynamics, ecological indicators

\section{Summary}

The effect of use and mineral supply on the botanical composition and yield of permanent grassland was studied for more than 20 years.

The experiment consisted of heavily fertilized hay plots ( $0, \mathrm{P}, \mathrm{K}, \mathrm{PK}, \mathrm{NPK}, \mathrm{Ca})$ and poorly fertilized pasture plots $(0, \mathrm{PK}, \mathrm{NPK}, \mathrm{Ca})$. Dry matter production was estimated yearly, and at regular intervals the botanical composition and soil fertility were analysed.

The unmanured pasture plots changed the least.

On some plots great changes have occurred, which are interesting with a view to ecological indicator values and population dynamics.

Moreover, some data are discussed on the uptake of minerals by the crop in different treatments.

\section{Introduction}

For the improvement and maintenance of cultivated and natural grasslands more knowledge is required on the effect of various plant nutrients on the botanical composition of the sward. In fact, since the middle of the nineteenth century many fertilizer experiments were carried out in north-western Europe. Because of the different initial situations of these experimental fields - with respect to mineral supply, soil moisture condition and botanical composition - the results of these experiments often varied widely. Moreover, these studies were mainly done in hayfields (sometimes followed by aftermath grazing). Because the botanical composition was analysed only once or at intervals of 5 years or more, the dynamics of plant populations remained obscure.

To avoid these shortcomings de Vries (Kruijne et al., 1967) in his study on the ef- 
fect of environmental factors (habitat factors, including plant nutrients) on the behaviour of grassland species chose another approach, that is the correlative, ecological research. In this study the greatest possible number of habitat factors was measured and the botanical composition of a great number of grassland fields analysed. This work yielded many interesting data, but because of the interrelationship of the different habitat factors, the causal factor for the presence or absence of a particular plant species was not easy to indicate. For instance, in the Netherlands the soil fertility of the permanent pastures near the farm buildings is much higher than that of the hayfields, which are more distant and hard to reach; because of this, type of use and mineral supply of grassland are distinctly related.

To separate some of these interrelated factors, the effect on the botanical composition was studied of heavy fertilizer dressings under hayfield conditions and light fertilizer dressings under grazing; the experiment was set out on a low-productive, poorly managed alternate pasture on heavy river-clay soil. In the period 1957-1978 the dry matter yield was measured annually and the botanical composition analysed almost every year. This report deals with the results obtained.

\section{Experimental lay-out}

The experiment consisted of 6 separate pasture plots of $1800 \mathrm{~m}^{2}$ and 12 hay plots of $40 \mathrm{~m}^{2}(16 \mathrm{~m} \times 2.5 \mathrm{~m})$. The pasture plots were set out in 1957 and the hay plots in 1958 on an old alternate pasture extensively grazed (every other year a hay cut) on heavy clay soil near Wageningen (Elberse, 1966). The main species were Holcus lanatus, Anthoxanthum odoratum, Festuca rubra and Agrostis spp.

The pasture plots were grazed 3 to 4 times a year by young cattle. To prevent transfer of minerals the cattle grazed on a non-fertilized strip for some days, before grazing on the pasture plots. The hay plots were hayed on the plot in the second half of June (sometimes the first half of July) and a second cut was harvested in October/November.

The fertilizer treatment of the pasture plots was $0, \mathrm{PK}, \mathrm{NPK}$ and Ca. 0 and NPK were replicated. The applications were $40 \mathrm{~kg} \mathrm{P}_{2} \mathrm{O}_{5} \mathrm{ha}^{-1}, 60 \mathrm{~kg} \mathrm{~K}_{2} \mathrm{O} \mathrm{ha}{ }^{-1}, 1000 \mathrm{~kg}$ $\mathrm{CaO} \mathrm{ha}{ }^{-1}$, and $60 \mathrm{~kg} \mathrm{~N} \mathrm{ha}^{-1}$, at two equal rates of $30 \mathrm{~kg} \mathrm{~N} \mathrm{ha}^{-1}$ in spring and in $\mathrm{Au}-$ gust. The treatments of the hay plots (in duplo) were $0, \mathrm{~K}, \mathrm{P}, \mathrm{PK}, \mathrm{NPK}$ and $\mathrm{Ca}(400$ $\mathrm{kg} \mathrm{K}_{2} \mathrm{O} \mathrm{ha}^{-1}, 120 \mathrm{~kg} \mathrm{P}_{2} \mathrm{O}_{5}$ ha $^{-1}, 160 \mathrm{~kg} \mathrm{~N} \mathrm{ha}^{-1}$ and $1000 \mathrm{~kg} \mathrm{CaO} \mathrm{ha}^{-1}$ ). Until 1964, 100 $\mathrm{kg} \mathrm{N} \mathrm{ha}^{-1}$ was applied in spring; since $1964,100 \mathrm{~kg} \mathrm{~N}^{-1}$ has been applied in spring and $60 \mathrm{~kg} \mathrm{~N} \mathrm{ha}^{-1}$ after haying. The fertilizers used were superphosphate, potassium sulphate, ammonium nitrate and lime marl. The first year no fertilizers were applied in order to study the initial situation.

Soil samples were taken at intervals of $4-7$ years. Per plot 50 borings of $2.4 \mathrm{~cm}$ diameter and $5 \mathrm{~cm}$ deep were collected at random and analysed at the Laboratory of Soil and Crop Testing, Oosterbeek. The first samples were taken before the fertilizers were applied (for the pasture plots 1958 and for the hay plots 1959).

Yields of the pasture plots were estimated by harvesting the grass grown under cages $(4.2 \mathrm{~m} \times 1.2 \mathrm{~m})$ (Bosch, 1956) at the end of May, in August and in October. In 1957 and 1958 there were two cages per plot and since 1959 four cages per plot. 
The cages were moved every February. Of the hayfields a strip of $1 \mathrm{~m}$ over the length of the plot was harvested. Fresh weight was recorded and after estimating dry weight content, the dry matter yield was calculated. In the harvests of the hay plots of 1977 the content of $\mathrm{N}$ and in those of 1978 the contents of $\mathrm{N}, \mathrm{P}$ and $\mathrm{K}$ were determined.

The botanical composition was analysed by the $25 \mathrm{~cm}^{2}$ frequency and order method of de Vries (1937). In the first half of May, 50 samples of $25 \mathrm{~cm}^{2}$ were taken on each pasture plot along the diagonal and two parallel lines on both sides of the diagonal. Until 1964, in the second half of May, 30 samples of $25 \mathrm{~cm}^{2}$ were taken on each hay plot along two parallel lines in the length of the plot and since 1964, 50 samples along three parallel lines in the length of the plot. The number of species present in 30 samples was converted to 50 samples with a graphical method. In each sample the presence of a species was recorded and the frequency percentage $(\mathrm{F} \%)$ estimated. The first three ranks, in terms of bulk, were also recorded. From these data dry-weight-rank percentages (DWR\%) were calculated (de Vries, 1937; 't Mannetje \& Haydock, 1963). In 1966 and 1968, 50 samples were collected from the swath of the hay plots and dry-weight percentages (DW\%) of the plant species were estimated (de Vries, 1949).

\section{Soil analyses}

Table 1 shows the results of the soil analyses of the various treatments. In the course of the years the organic matter content decreased with both types of use. The decrease is more distinct on the hay plots than on the pasture plots. The use of lime enlarged the reduction in the organic matter content. As an average of the two types of use this content decreased with 0.3 percentage units per year on the Ca treatments.

At the beginning of the experiment the $\mathrm{pH}$ value was somewhat higher on the pasture plots than on the hay plots. Liming increased the $\mathrm{pH}$ value to 6.5 ; this rise mainly occurred in the first 5 years of the experimental period. In 1978 the $\mathrm{pH}$ of the deeper soil layers $(5-25 \mathrm{~cm})$ increased to 6.5 too. After 17 years of liming the soil of the hay and pasture plots contained 3.5 and $4.0 \%$ of $\mathrm{CaCO}_{3}$, respectively. In the other fertilizer treatments the $\mathrm{pH}$ value continued to decrease through the years at an average of $0.1 \mathrm{pH}$ unit in 5 years.

The phosphorus and potassium contents in the soil at the beginning of the experiment were too low to produce high grass yields. On the plots without phosphate fertilizer the phosphate status remained the same when hayed, but when grazed the phosphate content rose slightly. This may be caused by the plant taking up phosphate from deeper soil layers, $P$ which accumulates with grazing via the droppings in the top soil layer $(0-5 \mathrm{~cm})$. On the plots without potassium fertilizer the potassium content in the soil decreased when hayed, but when grazed the potassium status remained almost the same.

On the plots with phosphate fertilizer the phosphate status in the hay plots rose sharply, because of the wide difference between fertilizer input and removal with the hay. In 1978, for instance, $20 \mathrm{~kg} \mathrm{P}$ per ha was removed from the PK treatment, 
Table 1. Soil analyses $(0-5 \mathrm{~cm})$ of the various treatments in different years.

\begin{tabular}{|c|c|c|c|c|c|c|c|c|c|c|c|c|c|}
\hline \multirow[b]{2}{*}{ Hayfield } & \multirow{2}{*}{$\frac{\text { Organic matter }(\%)}{1959196319701976}$} & \multicolumn{4}{|c|}{$\mathrm{pH}-\mathrm{KCl}$} & \multicolumn{4}{|c|}{$\mathrm{P}_{2} \mathrm{O}_{5}(\mathrm{mg} / 100 \mathrm{~g}$ soil $)$} & \multicolumn{4}{|c|}{$\mathrm{K}_{2} \mathrm{O}(\mathrm{mg} / 100 \mathrm{~g}$ soil $)$} \\
\hline & & 1959 & 1963 & 1970 & 1976 & 195 & 1963 & 1970 & 1976 & 195 & 1963 & 1970 & 1976 \\
\hline 0 & $\begin{array}{llll}21.2 & 20.2 & 20.7 & 18.2\end{array}$ & 4.3 & 4.2 & 4.0 & 3.8 & 7 & 8 & 10 & 9 & 28 & 16 & 18 & 20 \\
\hline $\mathrm{K}$ & $\begin{array}{llll}22.3 & 20.2 & 20.0 & 18.7\end{array}$ & 4.2 & 4.1 & 3.9 & 3.8 & 7 & 8 & 8 & 6 & 32 & 63 & 95 & 112 \\
\hline $\mathbf{P}$ & $\begin{array}{llll}22.2 & 21.7 & 20.6 & 18.9\end{array}$ & 4.3 & 4.3 & 4.4 & 4.1 & 6 & 42 & 62 & 75 & 31 & 17 & 19 & 19 \\
\hline PK & $\begin{array}{llll}22.4 & 21.0 & 21.1 & 19.7\end{array}$ & 4.4 & 4.1 & 4.0 & 3.9 & 7 & 31 & 61 & 81 & 32 & 60 & 86 & 82 \\
\hline $\mathrm{Ca}$ & $\begin{array}{llll}22.4 & 19.8 & 19.5 & 16.9\end{array}$ & 4.3 & 6.2 & 6.5 & 6.6 & 8 & 9 & 9 & 8 & 29 & 13 & 14 & 17 \\
\hline NPK & $\begin{array}{llll}21.8 & 20.7 & 19.7 & 18.2\end{array}$ & 4.3 & 4.3 & 4.0 & 3.8 & 6 & 25 & 46 & 57 & 31 & 41 & 62 & 48 \\
\hline Pasture & 1958196319701976 & 1958 & 1963 & 1970 & 1976 & 195 & 1963 & 197 & 1976 & 195 & 1963 & 1970 & 1976 \\
\hline 0 & $\begin{array}{llll}23.9 & 22.2 & 21.8 & 20.9\end{array}$ & 4.8 & 4.6 & 4.5 & 4.5 & 7 & 9 & 9 & 10 & 31 & 20 & 28 & 35 \\
\hline PK & $22.4-22.721 .3$ & 4.7 & 4.5 & 4.4 & 4.3 & 5 & 11 & 18 & 23 & 25 & 25 & 31 & 33 \\
\hline $\mathrm{Ca}$ & $\begin{array}{llll}22.3 & 20.1 & 19.7 & 18.2\end{array}$ & 4.9 & 6.4 & 6.7 & 6.5 & 7 & 11 & 11 & 12 & 26 & 19 & 19 & 21 \\
\hline NPK & $\begin{array}{llll}22.5 & 21.7 & 22.9 & 22.3\end{array}$ & 4.8 & 4.7 & 4.5 & 4.5 & 7 & 11 & 21 & 26 & 25 & 23 & 30 & 33 \\
\hline
\end{tabular}

whereas the fertilizer input was $52 \mathrm{~kg} P$ per ha. The lower $P$ dressings on the pasture plots brought about a rather good phosphate status of the soil after 17 years. In the hay plots fertilized with potassium the potassium content in the soil increased considerably. From 1974 both phosphate and potassium have been applied every other year. Potassium removal undoubtedly was the highest on the NPK plot. In 1978, $291 \mathrm{~kg} \mathrm{~K}$ per ha was removed with the hay, whereas fertilizer input was $332 \mathrm{~kg} \mathrm{~K}$ per ha. The lower potassium applications to the grazed plots have brought about a rather good potassium status of the soil.

\section{Yields}

The dry matter yields - averages of 5 years - for the various treatments are mentioned in Table 2. The table shows that the yields of the pasture plots are higher than those of the hay plots. The higher yield level with grazing for the major part is caused by the circulation of minerals, which are largely returned to the pasture by cattle as dung and urine. During the experiment the average annual yield of the 0 treatments with grazing was $2.4 \mathrm{t}$ (tonnes) of dry matter per ha higher than with haying; on the NPK treatments this difference is $0.9 \mathrm{t}$ of dry matter in favour of grazing, despite the $\mathrm{N}$ treatments on the hay plots being $100 \mathrm{~kg} \mathrm{~N}$ per ha higher. However, the first cut on the pasture plots was harvested usually on 2 June, that on the hay plots on 24 June, so about three weeks later. In this period the average daily growth rate on the NPK-hay plots was $58 \mathrm{~kg}$ dry matter per ha, which was rather low. The sward in this treatment consisted mainly of Alopecurus pratensis, an earlyflowering grass species, of which the photosynthesis will soon decrease when cut late. Moreover, after a late first cut, the regrowth of such a sward will be slow in starting. We also draw attention to the phenomenon that the dry matter yields under cages (estimation method on pasture plots) may be up to $15 \%$ higher than those in the field (Jagtenberg \& de Boer, 1958). 
Table 2. Dry matter yields of the various treatments, averaged over five years and expressed in tonnes per ha.

\begin{tabular}{|c|c|c|c|c|c|c|c|c|}
\hline & \multicolumn{4}{|l|}{ Hayfield } & \multicolumn{4}{|l|}{ Pasture } \\
\hline & $1959 / 63$ & $1964 / 68$ & $1969 / 73$ & $1974 / 78$ & $1959 / 63$ & $1964 / 68$ & $1969 / 73$ & $1974 / 78$ \\
\hline 0 & 5.2 & 4.8 & 5.0 & 4.1 & 7.6 & 7.1 & 6.6 & 7.3 \\
\hline $\mathrm{K}$ & 4.9 & 4.0 & 4.4 & 4.0 & & & & \\
\hline $\mathrm{P}$ & 5.7 & 4.9 & 6.0 & 5.2 & & & & \\
\hline PK & 6.1 & 5.8 & 6.2 & 4.8 & 8.7 & 8.6 & 8.1 & 8.6 \\
\hline $\mathrm{Ca}$ & 5.8 & 5.6 & 6.6 & 5.8 & 9.8 & 9.1 & 8.9 & 9.9 \\
\hline NPK & 8.6 & 9.0 & 10.0 & 7.8 & 10.0 & 10.2 & 9.3 & 9.4 \\
\hline
\end{tabular}

When hayed the yield of the $\mathrm{K}$ treatment is lower than that of the 0 treatment. Without fertilizer application the annual yield of the sward under normal weather conditions after 17 years of haying was about $5 \mathrm{t}$ of dry matter per ha. On the hay plots the yields increase according to the fertilizer treatments P, PK, Ca and NPK. On the pasture plots with respect to the fertilizer treatment the same order in yields can be observed $0, \mathrm{PK}, \mathrm{Ca}$ and NPK, although in the last 5 years the average yield of the Ca treatment was higher than that of the NPK treatment. These data clearly show the importance of the phosphate fertilizer in comparison to potassium.

Fig. 1 shows the yields during the experimental period for the treatments 0 , PK, and NPK with haying and with grazing. The figure also shows the rainfall in the months April to September in the different experimental years. The yields vary widely in the years. Since these fluctuations show parallelism on the hay and pasture plots, they are mainly caused by the differing weather conditions. The low yields in 1959 and 1976, for instance, were especially caused by the extremely dry summers; in 1962 the summer was rather dry, but cold; the lower yields on the pasture plots in 1970 and on the hay plots in 1971 cannot be explained in this way.

The high yields on the $\mathrm{Ca}$ treatments were caused by mineralization of the soil nitrogen. From the nitrogen contents in the grass determined in 1977 and 1978, it may be inferred that in these two years the herbage yield of the 0 and $\mathrm{Ca}$ treatments of the hay plots contained on an average 84 and $115 \mathrm{~kg} \mathrm{~N}$ per ha, respectively. The decrease in the organic matter content on this Ca treatment is $2.5 \%$ more than on the 0 treatment. With a volume weight of the soil of 1.0 and a nitrogen content in the organic matter of $4.5 \%$ calculation showed that the average annual amount of nitrogen available in the $0-5 \mathrm{~cm}$ soil layer on the Ca treatment was $33 \mathrm{~kg} \mathrm{~N} \mathrm{ha}^{-1}$ year $^{-1}$ more than on the 0 treatment. The contribution of nitrogen from the deeper soil layers and from the rain in both treatments is some $40 \mathrm{~kg} \mathrm{~N} \mathrm{ha}^{-1} \mathrm{year}^{-1}$. A comparison of the nitrogen harvested with the herbage of the 0 and NPK hay plots (84 and 172 $\mathrm{kg} \mathrm{N} / \mathrm{ha}$, respectively) in 1977 and 1978 showed that of the $160 \mathrm{~kg}$ nitrogen applied the recovery was on an average $55.6 \%$. 


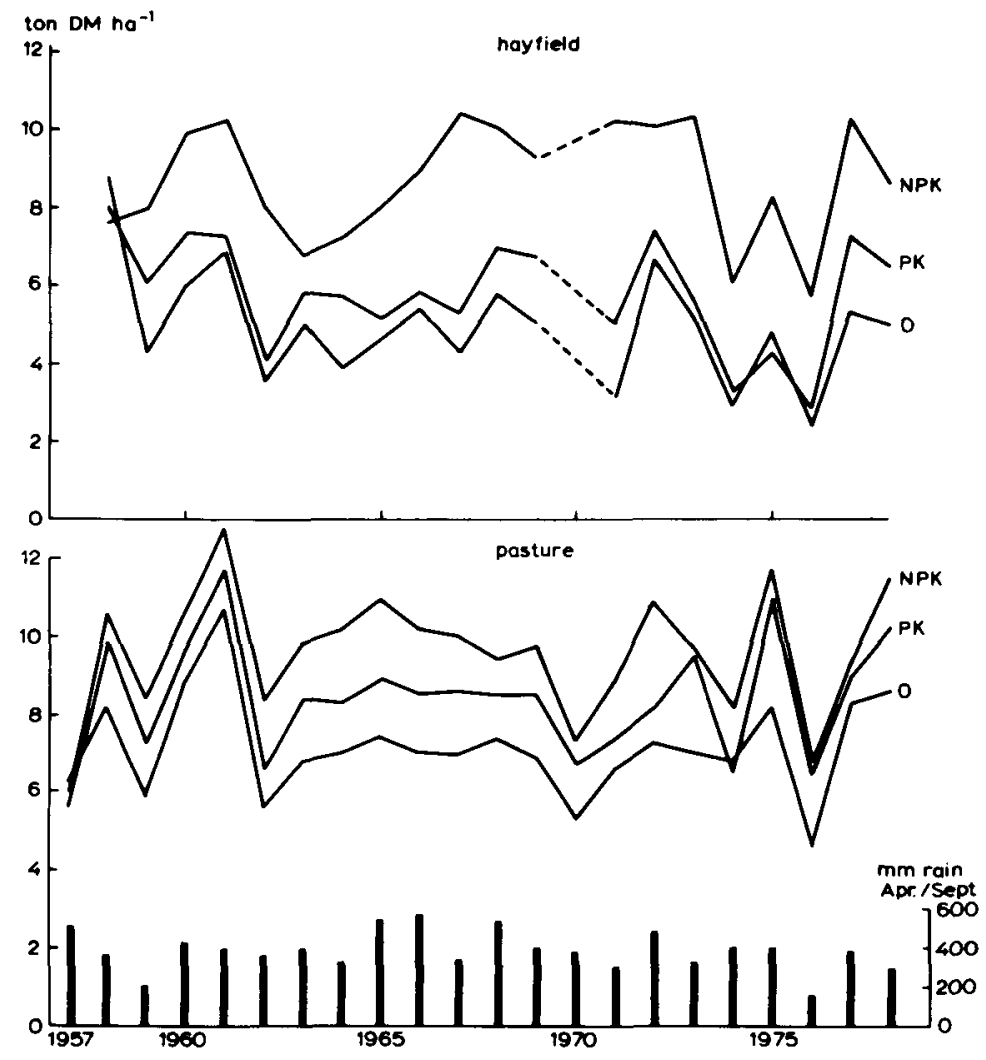

Fig. 1. Average dry matter yields of hayfields and pastures on the treatments 0 , PK and NPK during a period of 20 years (way of harvesting and amount of fertilizers, see text). On the bottom $\mathrm{mm}$ rainfall during the growing season April-September.

\section{Botanical composition}

\section{Species diversity}

Species diversity on this heavy river-clay soil is great. In the hay plots with a total area of $480 \mathrm{~m}^{2}, 57$ species were found in 360 samples of $25 \mathrm{~cm}^{2}$ at the start of the experiment, whereas in the pasture plots with a total area 23 times larger, 66 species were recorded in 300 samples of $25 \mathrm{~cm}^{2}$. In the whole experimental field 73 different species were found. In the last 20 years 109 species were recorded in the samples: 29 grasses, 8 legumes, 15 grasslike weeds and 57 herbs.

Table 3 shows the number of species in the different treatments in the past 20 years. Species diversity in the pasture plots seems to be greater than in the hay plots, but this is only because the pasture plots are 45 times larger than the hay plots. 
Table 3. Number of species in 50 samples of $25 \mathrm{~cm}^{2}$ in the different years. Average of two replicates.

\begin{tabular}{|c|c|c|c|c|c|c|c|c|c|c|}
\hline & \multicolumn{6}{|c|}{ Hayfield $\left(40 \mathrm{~m}^{2}\right)$} & \multicolumn{4}{|c|}{ Pasture $\left(1800 \mathrm{~m}^{2}\right)$} \\
\hline & 0 & $\mathrm{~K}$ & $P$ & PK & $\mathrm{Ca}$ & NPK & 0 & $\mathrm{PK}^{*}$ & $\mathrm{Ca}^{*}$ & NPK \\
\hline 1957 & & & & & & & 49 & 45 & 36 & 44 \\
\hline 1958 & 33 & 36 & 38 & 39 & 41 & 38 & & & & \\
\hline 1959 & & & & & & & 48 & 46 & 34 & 42 \\
\hline 1960 & 33 & 36 & 30 & 38 & 36 & 35 & & & & \\
\hline 1961 & 40 & 35 & 38 & 38 & 40 & 26 & 44 & 43 & 30 & 37 \\
\hline 1962 & 39 & 41 & 43 & 44 & 40 & 28 & 50 & 49 & 40 & 39 \\
\hline 1963 & 35 & 34 & 39 & 39 & 39 & 24 & 45 & 40 & 34 & 30 \\
\hline 1964 & 32 & 32 & 38 & 34 & 35 & 26 & 38 & 34 & 30 & 27 \\
\hline 1965 & 29 & 31 & 37 & 32 & 37 & 21 & 41 & 35 & 33 & 31 \\
\hline 1966 & 34 & 34 & 36 & 31 & 31 & 18 & 39 & 33 & 34 & 26 \\
\hline 1967 & $26^{*}$ & $27^{*}$ & $36^{*}$ & $33^{*}$ & $32^{*}$ & 19 & & & & \\
\hline 1969 & & & & & & & 41 & 32 & 30 & 26 \\
\hline 1971 & 32 & 32 & 39 & 29 & 30 & 14 & 39 & 30 & 28 & 26 \\
\hline 1973 & 31 & 35 & 35 & 27 & 32 & 14 & 40 & 28 & & 24 \\
\hline 1976 & 23 & 25 & 29 & 25 & 28 & 13 & 33 & 25 & 26 & 22 \\
\hline 1978 & 26 & 29 & 35 & 24 & 26 & 9 & 36 & 22 & 21 & 25 \\
\hline
\end{tabular}

* One replicate.

In all the treatments including the unmanured, the number of species decreased. As mentioned before, this field used to be an alternate pasture, whereas at present one part is hayed only and the other part is grazed only. The change-over to these extreme types of use is perhaps one of the reasons of the decline in the number of species.

The decline was least in the hay plots with a $\mathrm{P}$ content increasing up to $75 \mathrm{mg}$ $\mathrm{P}_{2} \mathrm{O}_{5} / 100 \mathrm{~g}$ soil, followed by the unmanured and $\mathrm{K}$ plots. The number of species dropped to less than 10 in the NPK hay plots. This decrease was undoubtedly caused by the severe competition for light by the dominance of some highly productive grass species. Within 7 years (1958-1965) the number of species was almost halved, which was accompanied with explosive development of $A$. pratensis and Poa pratensis (see also Fig. 2).

\section{Changes in biomass within 10 years}

Table 4 mentions only those species present with at least $5 \% \mathrm{DW}$ (or DWR) in the biomass either at the start of the experiment or after about 10 years.

Originally, the grass species Holcus lanatus, Anthoxanthum odoratum, Festuca rubra and Agrostis spp. made up about half of the biomass. This group persisted in the unmanured plots, but was reduced to $6 \%$ or less in the Ca pasture plot and in the NPK hay plots, respectively. In the Ca pasture plot this group was replaced mainly by Lolium perenne and Poa trivialis and in the NPK hay plots by $A$. pratensis and Dactylis glomerata (see also Fig. 2). L. perenne and $P$. trivialis also showed a marked increase in the NPK pasture plots. In $1962 \mathrm{H}$. lanatus almost disappeared 

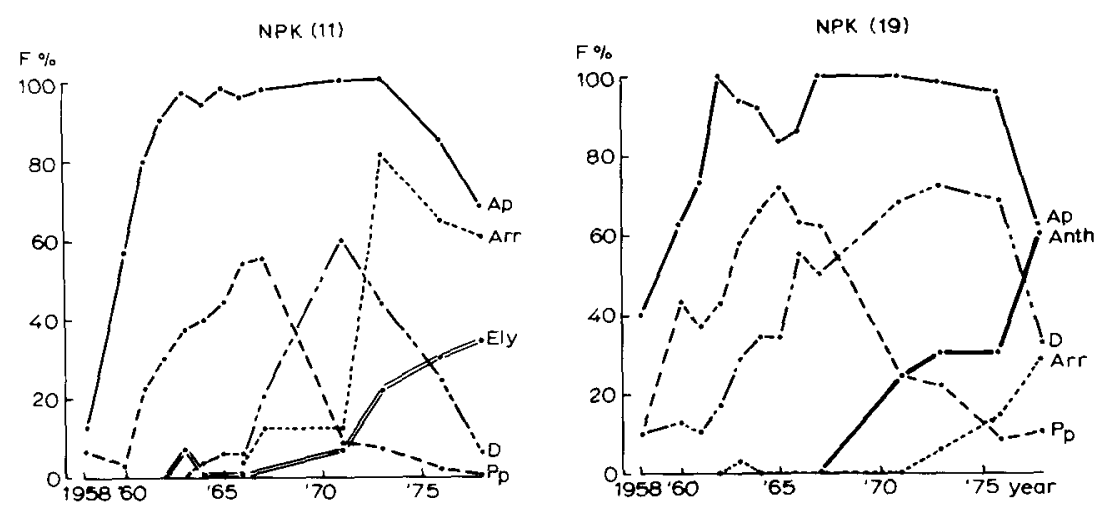

Fig. 2. Frequency percentages of some important species on the NPK plots 11 and 19 plotted against time. For symbols, see Fig. 8.

Table 4. DW and DWR percentages of the species which were at least with $5 \%$ in the biomass either at the start of the experiment (1958) or after about 10 years on the different hay and pasture plots resp.

\begin{tabular}{|c|c|c|c|c|c|c|c|c|c|c|c|}
\hline & \multirow[t]{2}{*}{$\begin{array}{l}\text { DWR\% } \\
1958\end{array}$} & \multicolumn{6}{|c|}{$\begin{array}{l}\text { Hayfield (DW\%), } \\
1966+1968\end{array}$} & \multicolumn{4}{|c|}{$\begin{array}{l}\text { Pasture (DWR\%), } \\
1966+1969\end{array}$} \\
\hline & & 0 & $\mathrm{~K}$ & $\mathrm{P}$ & PK & $\mathrm{Ca}$ & NPK & 0 & PK & $\mathrm{Ca}$ & NPK \\
\hline Agrostis stolonifera + A. tenuis & 10 & 14 & 9 & 7 & 7 & 4 & 2 & 8 & 7 & 4 & 6 \\
\hline Alopecurus pratensis & 4 & 8 & 6 & 6 & 14 & 18 & 67 & 5 & 6 & 9 & 8 \\
\hline Anthoxanthum odoratum & 12 & 11 & 14 & 13 & 7 & + & + & 18 & 10 & 1 & 4 \\
\hline Dactylis glomerata & 2 & 1 & 7 & 1 & 15 & 6 & 20 & 1 & + & + & 2 \\
\hline Festuca rubra & 11 & 14 & 11 & 10 & 6 & 7 & + & 16 & 8 & + & 5 \\
\hline Holcus lanatus & 16 & 5 & 2 & 6 & 2 & 3 & + & 11 & 9 & 1 & 11 \\
\hline Lolium perenne & 4 & + & + & 1 & 1 & + & & 3 & 9 & 28 & 17 \\
\hline Poa pratensis & 1 & 2 & 2 & 1 & 1 & 12 & 3 & + & + & 1 & 1 \\
\hline Poa trivialis & 2 & + & & + & + & 3 & + & 4 & 12 & 23 & 25 \\
\hline Other grasses & 13 & 5 & 6 & 3 & 4 & 10 & 7 & 10 & 13 & 16 & 14 \\
\hline Trifolium repens & + & + & + & + & + & + & & 2 & 9 & 1 & 3 \\
\hline Other legumes & 1 & 4 & 2 & 3 & 10 & 4 & + & & 2 & & \\
\hline Grasslike weeds & 3 & 7 & 4 & 2 & 2 & + & + & 3 & 1 & 3 & + \\
\hline Achillea ptarmica & + & 4 & 8 & 9 & 5 & + & & + & + & & \\
\hline Centaurea pratensis & 3 & 9 & 13 & 10 & 4 & 11 & & 2 & + & + & \\
\hline Chrysanthemum leucanthemum & 3 & 3 & 5 & 6 & 2 & 1 & + & 1 & 1 & + & + \\
\hline Plantago lanceolata & + & 3 & + & 6 & 1 & 7 & & 1 & & & \\
\hline Ranunculus acris & 3 & 6 & 5 & 9 & 6 & 5 & + & 7 & 7 & 5 & 2 \\
\hline Ranunculus repens & 2 & + & + & 1 & + & 1 & + & 2 & 3 & 5 & 1 \\
\hline Rumex acetosa & 5 & 3 & 3 & 4 & 5 & 4 & 1 & 3 & 1 & + & 1 \\
\hline Other herbs & 5 & 1 & 3 & 2 & 8 & 4 & & 4 & 2 & 4 & \\
\hline
\end{tabular}


from all the hay plots; probably because of a period of severe frost in March 1962.

Another striking phenomenon is the high percentage of legumes in the PK plots (about $10 \%$ ) and the finding that the total portion of herbs in the $\mathrm{P}$ hay plots was the highest and that in the NPK plots the lowest.

\section{Frequency percentages}

Frequency percentages (F\%) were determined in 13 years out of the first 20 . So, the behaviour of all the species in the various treatments could be observed through the years. Table 5 only shows the F\%s in the years $1957 / 58$ and 1978 of those species, which were present at least once with an F\% of 5 or more. With our reflections on the behaviour of the species in time, the $\mathrm{F} \% \mathrm{~s}$ in the intermediate years are also considered. Moreover, graphs have been drawn of those species which show a particular curve during time.

Unmanured plots. Some species in the unmanured plots showed a sharp decrease or even disappeared; hence this process is independent of the type of use and not brought about by fertilizers. The most important decreasers are Agrostis canina, Cynosurus cristatus, Festuca pratensis, $P$. trivialis, Trisetum flavescens and Cardamine pratensis. The decline in $A$. canina, $P$. trivialis, $C$. pratensis, Carex panicea, Carex nigra and Lysimachia nummularia according to Kruijne et al. (1967) and de Boer (1956) indicates less humid conditions, which agrees with the observation that drainage has been improved in the past 20 years. However, the decline in the indicators of dry conditions, $T$. flavescens and Luzula campestris, does not correspond (Kruijne et al., 1967).

In the unmanured hay plots, among others, Deschampsia cespitosa, H. lanatus, $L$. perenne and Trifolium repens decreased considerably. Since $L$. perenne and $T$. repens are typical indicators of grazed conditions, they practically disappeared from the hay plots within 10 years (see also Tables 4 and 5). Noteworthy is that the only species with a consistent increase was the indicator of rather fertile conditions, $D$. glomerata, on one of the unmanured hay plots.

In the unmanured pasture plots the average decline in the number of species was 13, mainly grasslike weeds and legumes; in the unmanured hay plots mainly grasses disappeared.

$K$ plots. The changes in the $\mathrm{F} \%$ in time on the $\mathrm{K}$ hay plots do not show important differences with those on the unmanured hay plots. Perhaps Leontodon taraxacoides and Hypochaeris radicata have increased somewhat recently; for the latter species this was not associated with the $\mathrm{K}$ treatment, because the same tendency occurred on the other low-productive hay plots $(0, \mathrm{P}, \mathrm{PK})$.

$P K$ plots. On an average these plots produced over $1 \mathrm{t} \mathrm{DM} \mathrm{ha-1} \mathrm{more} \mathrm{than} \mathrm{the} \mathrm{un-}$ manured plots (Table 2). Higher fertility stimulates the productive grasses, and so the less productive grasses are suppressed (Tables 4 and 5). Independent of the type of use the less productive grasses, Agrostis spp. and A. odoratum, decreased 


\section{W. TH. ELBERSE, J. P. VAN DEN BERGH AND J. G. P. DIRVEN}

Table 5. Frequency percentages of the frequently occurring species ${ }^{1}$ on the different plots in 1978 and the average $\mathrm{F} \%$ of all the hay plots in 1958 and of all the pasture plots in 1957.

Agrostis canina

Agrostis tenuis + A. stolonifera

Anthoxanthum odoratum

Arrhenatherum elatius

Briza media

Cynosurus cristatus

Dactylis glomerata

Deschampsia cespitosa

Elytrigia repens

Festuca pratensis

Festuca rubra

Holcus lanatus

Lolium perenne

Phleum pratense

Poa annua

Poa pratensis

Poa trivialis

Trisetum flavescens

Lathyrus pratensis

Lotus uliginosus

Trifolium dubium

Trifolium pratense

Trifolium repens

Vicia cracca

Carex acuta

Carex nigra

Carex panicea

Equisetum palustre

Juncus effusus

Luzula campestris

Achillea millefolium

Achillea ptarmica

Allium vineale

Anthriscus sylvestris

Bellis perennis

Cardamine pratensis

Centaurea pratensis

Cerastium fontanum spp. triviale

Chrysanthemum leucanthemum

Galium verum

Hypochaeris radicata

Leontodon autumnalis
Alopecurus pratensis

Hordeum secalinum

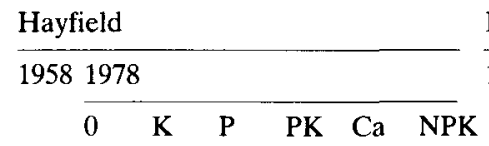

Pasture

19571978

$\begin{array}{rrrrrrrrrrrr}23 & 6 & 4 & 1 & & 1 & & 15 & 6 & & & \\ 85 & 77 & 82 & 61 & 40 & 3 & 1 & 87 & 59 & 28 & 46 & 33 \\ 30 & 35 & 30 & 55 & 63 & 69 & 65 & 20 & 31 & 52 & 68 & 58 \\ 74 & 53 & 38 & 46 & 46 & . & & 55 & 43 & 10 & 2 & 4 \\ & 1 & 5 & 19 & 7 & 78 & 44 & 1 & & & . & 1 \\ 1 & . & 6 & . & & . & & 4 & & & & \\ 19 & & & 1 & 1 & & & 24 & 10 & . & 4 & 1 \\ 6 & 24 & 29 & 40 & 83 & 44 & 19 & 11 & 12 & 8 & 2 & 18 \\ 19 & 2 & 2 & 4 & 2 & 1 & & 14 & 14 & 24 & 4 & 17 \\ 1 * * & 4 & 1 & 5 & & 2 & 17^{*} & & 6 & 6 & & 21 \\ 9 & 1 & . & 2 & . & 2 & 1 & 22 & 7 & 2 & 4 & 4 \\ 84 & 96 & 88 & 92 & 59 & 19 & & 68 & 82 & 74 & & 26 \\ 58 & 9 & 19 & 40 & 39 & 5 & 10 & 56 & 54 & 72 & 10 & 53 \\ 8 & & 3 & 2 & . & & & 19 & 15 & 4 & 18 & 18 \\ 31 & 1 & . & 2 & & 1 & & 44 & 47 & 82 & 94 & 95 \\ 1 & & & 2 & & 1 & & 7 & 3 & 12 & 36 & 5 \\ 1 & & 1 & 1 & & & & 2 & . & 7 & . & 24 \\ 11 & 28 & 19 & 23 & 38 & 72 & 5 & 13 & 9 & 22 & 4 & 33 \\ 36 & . & . & 7 & 2 & 53 & 3 & 50 & 6 & 26 & 100 & 58 \\ 37 & 9 & 15 & 50 & 20 & 43 & . & 22 & 8 & 8 & . & 8\end{array}$$$
4
$$

$\begin{array}{rrrrrrr}6 & 2 & . & & 3 & & \\ 25 & & 4 & & 2 & & \\ 2 & 6 & 2 & 6 & 6 & 8 & \end{array}$

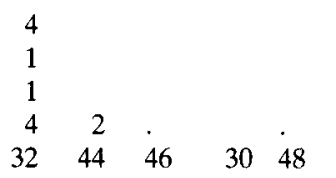

$\begin{array}{rrrrrrrrr}1 & . & 3 & 2 & 1 & . & 1 & 1 & \\ 10 & 7 & 5 & 8 & 6 & 1 & . & 10 & 2 \\ & & & & & & & 9 & \\ 2 & 4 & 4 & 7 & 2 & 2 & . & 1 & \\ 1 & & 1 & 1 & & & & 2 & \\ 16 & 1 & & 2 & & & & 10 & 4\end{array}$

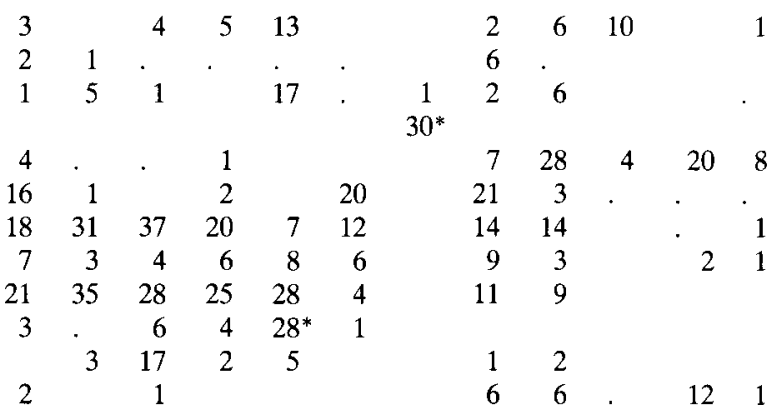


Table 5 (continued).

\begin{tabular}{|c|c|c|c|c|c|c|c|c|c|c|c|c|}
\hline & \multicolumn{7}{|c|}{ Hayfield } & \multicolumn{5}{|c|}{ Pasture } \\
\hline & \multicolumn{7}{|c|}{19581978} & \multirow[t]{2}{*}{1957} & \multicolumn{4}{|c|}{1978} \\
\hline & & 0 & $\mathrm{~K}$ & $\mathbf{P}$ & PK & $\mathrm{Ca}$ & NPK & & 0 & PK & $\mathrm{Ca}$ & NPK \\
\hline Leontodon taraxacoides & 8 & & 12 & & & & & 7 & 2 & & & \\
\hline Lysimachia nummularia & 14 & 4 & . & 1 & 1 & 2 & & 9 & 1 & & & \\
\hline Pimpinella saxifraga & 1 & 2 & & 1 & . & & & 1 & & & & \\
\hline $\begin{array}{l}\text { Plantago lanceolata } \\
\text { Prunella vulgaris }\end{array}$ & 3 & 2 & 5 & 18 & 8 & 7 & & $\begin{array}{l}1 \\
5\end{array}$ & 4 & & & \\
\hline Ranunculus acris & 45 & 6 & 9 & 21 & 4 & 38 & & 44 & 23 & 20 & 22 & 7 \\
\hline Ranunculus repens & 14 & 1 & & 6 & 1 & 6 & & 11 & 20 & 30 & 22 & 25 \\
\hline Rumex acetosa & 62 & 58 & 42 & 54 & 34 & 36 & . & 33 & 27 & 16 & 2 & 8 \\
\hline Stellaria graminea & 6 & 1 & . & 2 & . & & & 5 & 1 & & & \\
\hline Stellaria media & & & & & & & . & & 2 & 2 & 2 & 10 \\
\hline Taraxacum sect. Vulgaria & 6 & 1 & 2 & 1 & & 1 & & 14 & 13 & 2 & 8 & 3 \\
\hline Veronica chamaedrys & 5 & . & & 2 & . & 1 & & 2 & & & & \\
\hline Veronica serpyllifolia & & & & 6 & & 8 & & & & & & \\
\hline
\end{tabular}

${ }_{1}$ Names according to: Heukels-van Ooststroom, Flora van Nederland. Wolters-Noordhoff, Groningen, 1977.

Since 1975 found one time.

* On one replicate.

** On one replicate of the 0 treatment $13 \mathrm{~F} \%$.

Other species: Ajuga reptans, Alopecurus geniculatus, Bromus mollis, Capsella bursa-pastoris, Carex acutiformis, Carex disticha, Carex hirta, Carum carvi, Cirsium arvense, Cirsium palustre, Cirsium vulgare, Crepis biennis, Daucus carota, Eleocharis palustris, Equisetum arvense, Equisetum fluviatile, Festuca arundinacea, Festuca ovina, Ficaria verna, Filipendula ulmaria, Galium mollugo, Galium palustre, Galium saxatile, Galium uliginosum, Glechoma hederacea, Glyceria fluitans, Heracleum sphondylium, Hieracium lactucella, Hieracium pilosella, Holcus mollis, Juncus articulatus, Juncus bufonius, Juncus subuliflorus, Lotus corniculatus, Lychnis flos-cuculi, Medicago lupulina, Phalaris arundinacea, Pimpinella major, Plantago major, Poa palustris, Polygonum aviculare, Potentilla anserina, Potentilla erecta, Potentilla reptans, Ranunculus bulbosus, Ranunculus flammula, Rumex acetosella, Rumex thyrsiflorus, Senecio jacobaea, Succisa pratensis, Trifolium dubium, Veronica arvensis.

and the productive grasses, $A$. pratensis and $P$. pratensis, increased (on the hay plots the increase in $A$. pratensis occurred in one replicate only). In the first 15 years the unproductive grass, $F$. rubra, declined in the hay plots, but afterwards a remarkable recovery occurred in one replicate. In both hay plots the highly productive grass, $D$. glomerata, increased consistently up to a very high $\mathrm{F} \%$. Besides $D$. glomerata, the productive grass Arrhenatherum elatius has been increasing, since 1976. As expected $L$. perenne is becoming most important in the pasture plot. For the herbs, Centaurea pratensis decreased in all the PK plots, whereas Chrysanthemum leucanthemum decreased in the pasture plot and Allium vineale increased in the hay plots.

NPK plots. Because the early flowering grass species, $A$. pratensis, dominated in the hay plots within 4 years (Fig. 2), the hay and pasture plots differ widely in botanical composition. 


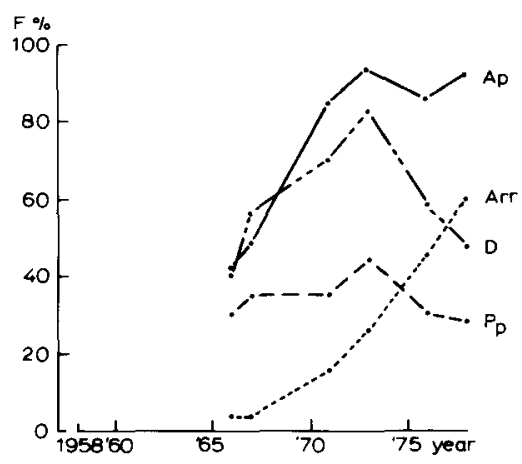

Fig. 3. Average frequency percentages of four grassspecies on the NPK-hay plots with a delayed $\mathrm{N}$ gift (see text). For symbols, see Fig. 8 .

In one of the hay plots species as, for instance, P. pratensis, D. glomerata and $A$. elatius, in turn, all show distinct rise-and-fall curves (van den Bergh, 1979). The same occurs in the replicate, but instead of A. elatius, Anthriscus sylvestris rose rapidly after 1967. This highly dynamic character of the vegetation with a succession of tall growing grasses may be caused by increasing fertility (Table 1). On the other hand, according to Kruijne et al. (1967), P. pratensis, D. glomerata and A. elatius in this order, indicate increasing dryness, which may reflect the improved drainage. All these species after some time showed a rather dispersed stand throughout the plot. Elytrigia repens, however, started at one end of the plot and is now occupying about one third of the plot in pure stand.

The number of species dropped rapidly and in about 6 years the dominating species, $H$. lanatus, $F$. rubra and $A$. odoratum were reduced to F\% $\leqslant 10$, for Agrostis spp., this took about 14 years.

Besides the NPK hay plots with $100 \mathrm{~kg} \mathrm{~N} \mathrm{ha}^{-1}$ in spring and $60 \mathrm{~kg} \mathrm{~N}^{-1}$ in summer, two plots, with $160 \mathrm{~kg} \mathrm{~N}^{-1}$ in summer were started on the same site 8 years later. This treatment was introduced to retard the early developing grass, $A$. pratensis, and to stimulate the later developing grasses, $D$. glomerata and $P$. pratensis. This effort was only partly successful, because $D$. glomerata increased right from the beginning (Fig. 3) and reached its maximum already after 7 years, but $A$. pratensis was hardly retarded. $P$. pratensis only showed a clear rise-and-fall curve in one of the replicates, in the other $A$. pratensis and D. glomerata were far ahead of $P$. pratensis already at the start. As in plot $11, A$. elatius came to full development after $D$. glomerata was declining.

The NPK pasture plots behaved much like the PK pasture plots, except for $F$. rubra showing a gradual decrease, $P$. trivialis persisting and $E$. repens, Poa annua, $P$. pratensis and Stellaria media showing a surprising increase in 1978.

Ca plots. For production these plots are in between the PK and the NPK plots and this also holds for the response of some grass species. The decline in Agrostis spp., $F$. rubra, $A$. odoratum and $H$. lanatus in the hay plots was intermediate to that of these species in the PK and NPK plots. This fall was compensated by the rise in $A$. elatius, $P$. pratensis, A. pratensis and $D$. glomerata. The change of the guards took 

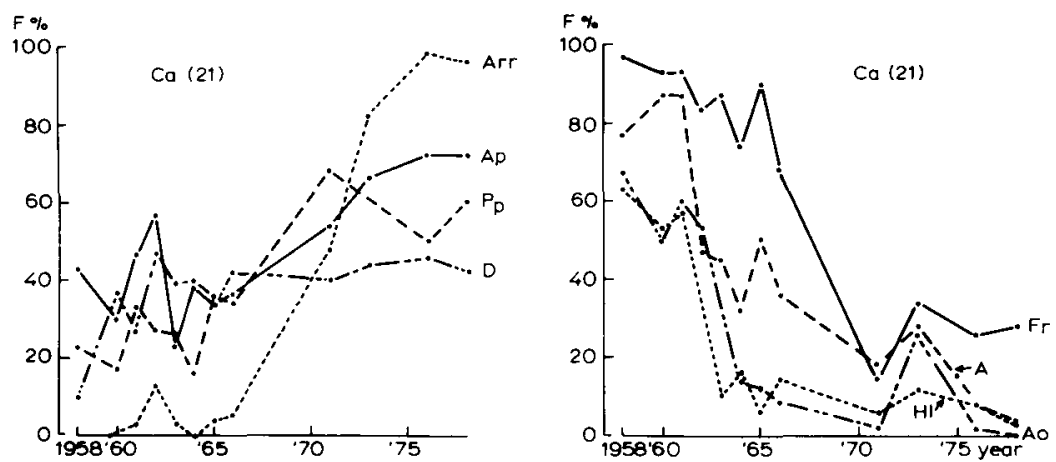

Fig. 4. Frequency percentages of some grasses on the Ca hay plot No 21; left the increasers and right the decreasers. For symbols, see Fig. 8.

place in the early $1960 \mathrm{~s}$ (Fig. 4). In this period the $\mathrm{pH}$ value rose from 4.3 to 6.2 (Table 1). F. rubra, $A$. odoratum and $H$. lanatus even showed a greater decrease in the pasture plot than in the NPK pasture plots.

$P$. trivialis responded positively in all the Ca plots, whereas $P$. pratensis showed the greatest response in the Ca hay plots and none at all in the pasture plot, Phleum pratense, however, in the pasture and not in the Ca hay plots.

$P$ plots. Most striking is that in the last 20 years the $\mathrm{F} \%$ of $H$. lanatus and Plantago lanceolata was nearly always higher in these $P$ hay plots than in all the other treatments.

\section{Response of the species to the treatments compared with that in the literature}

The main purpose of this field experiment is to give a more causal basis to the ecology of individual species by separating the environmental factors usually associated. For instance, the associations poor and hayfield, rich and pasture, high $\mathbf{P}$ and high $\mathrm{K}$ conditions were separated by making rich hayfield, poor pasture, high $\mathrm{P}$ and low $\mathrm{K}$ conditions and the reverse. These conditions were only partly realized, because of limited space, especially for the pasture plots. For acidity too, only under low fertility conditions rather high values $(\mathrm{pH}-\mathrm{KCl}=6.6)$ could be obtained by liming.

The response of the most important species to the treatments will be compared with the findings in the literature. However, we have to make a reserve. Both the findings in our own research and those in the literature (Williams, 1978; Watt, 1960,1971 ; etc.) show that the occurrence of species may fluctuate widely in the course of years. Therefore, it is rather pointless to compare our findings, which are based on 13 observations in 20 years, with one observation at the end of the experiment often given in literature.

Holcus lanatus. The response of $H$. lanatus is positive to phosphate fertilizer and negative to liming, whereas the species is much more persistent in the pasture plots than in the hay plots. 
According to Kruijne et al. (1967) H. lanatus shows its optimum in rather poor moderately acid hay pastures; other sources (Williams, 1978; Grundler \& Voigtländer, 1979; Zijlstra, 1937) mention that it is much stimulated by the ammonia fertilizers, which is accompanied with a decreasing $\mathrm{pH}$ value. $H$. lanatus decreases distinctly with liming (Williams, 1978; Zijlstra, 1937).

Striking is therefore that the species reacts positively to a one-sided phosphate application, under otherwise fairly acid and poor conditions. This does not agree with Arnold et al. (1976) who found on a meadow of 80 years, the highest percentage of $H$. lanatus in the NK plot and not in the P and NP plots. However, this NK plot had a $\mathrm{pH}-\mathrm{CaCl}_{2}=3.6$, whereas this $\mathrm{pH}$ value of the $\mathrm{P}$ and $\mathrm{NP}$ plot was 5.1 and 4.6 , respectively.

Perhaps, especially the low $\mathrm{pH}$ value is necessary for $H$. lanatus to become a dominant species.

Anthoxanthum odoratum. This species may show wide fluctuations from year to year, probably caused by the great differences in the number of seedlings brought on by changing weather conditions.

A. odoratum with both types of use responds negatively to NPK and Ca fertilizing and only with grazing negatively to PK. This agrees well with Kruijne et al. (1967) for fertilizer application, but for its indifference to the type of use not, because Kruijne et al. record a much lower frequency on pure pastures. The separation of environmental factors, shows that $A$. odoratum can withstand grazing excellently under poor conditions.

In the experimental field at Rothamsted (Williams, 1978) $H$. lanatus and $A$. odoratum alternated with each other in the unlimed parts of the N2P and N2PK treatments, which shows that the ecology of these species in these hayfields was much the same and that they both responded positively to a complete fertilizer application.

Festuca rubra. F. rubra is also a species indicating poor conditions. It has a somewhat higher frequency on the hay plots than in the pasture plots and shows a negative response to liming.

This corresponds closely with Kruijne et al.'s (1967) relative average frequencies, except that these figures show an increase in $F$. rubra at higher $\mathrm{pH}$ values. Striking is that in the Rothamsted plots (Williams, 1978), which received a onesided dressing, F. rubra responded positively to liming, whereas the findings of Arnold et al. (1976) showed that $F$. rubra is independent of the $\mathrm{pH}$ value. In the plots with $\mathrm{N}$ only, $F$. rubra rose sharply. These experiments also showed that the occurrence of $F$. rubra may fluctuate widely (Williams, 1978).

Agrostis spp. This group of species has declined everywhere, except for the 0 and $\mathrm{K}$ hay plots. This group is moreover rather persistent in the $\mathrm{P}$ hay and 0 pasture plots. Striking are the high F\%s of the Agrostis spp. in the Ca and NPK pasture plots compared with those in the Ca and NPK hay plots.

In Rothamsted (Williams, 1978) the weight percentage of Agrostis tenuis in- 
Table 6. DW percentages of 3 species in different years on the $\mathrm{N}_{2} \mathrm{P}$-ulimed treatment (plot $4^{2}$ ). This plot received nitrogen as ammonium sulphate (Williams, 1978).

\begin{tabular}{lrrrrrrrrrr}
\hline & 1862 & 1867 & 1872 & 1877 & 1903 & 1914 & 1919 & 1947 & 1949 & 1973 \\
& & & & & & & & & & \\
Agrostis tenuis & 19 & 14 & 21 & 24 & 2 & 13 & 4 & 69 & 36 & 24 \\
Anthoxanthum odoratum & 2 & 5 & 1 & 2 & 23 & 8 & 34 & 14 & 10 & 76 \\
Festuca rubra & 7 & 26 & 49 & 55 & 53 & 73 & 48 & 10 & 35 & - \\
\hline
\end{tabular}

creased to about 80 on the treatments with ammonium sulphate (SA) and SA $+\mathrm{K}$ only, which is remarkable! In Newcastle (Arnold et al., 1976), however, more $A$. tenuis occurred in the $\mathrm{P}$ and $\mathrm{NP}$ treatments than in the $\mathrm{N}$ and NK treatments.

How much these DW percentages are dependent on the year of sampling is illustrated by the following table after Williams (1978) (Rothamsted). Table 6 shows that a vegetation dominated by $F$. rubra can change in 30 years to one dominated by A. tenuis and after another 30 years into a vegetation dominated by Anthoxanthum odoratum.

Alopecurus pratensis. In contrast with Agrostis spp., A. pratensis increased in all the treatments, except for the 0 and $\mathrm{K}$ hay plots. This species indicating fertility developed explosively in the hay plots with complete fertilizer application, but after about 17 years it started to decline (Fig. 2, possible competition of E. repens and Anthriscus sylvestris). Striking is that it indicates grazing nor haying, whereas the findings of Kruijne et al. (1967) clearly showed the lowest relative average frequency ( $\mathrm{raF}$ ) with grazing.

Another contrast is that $A$. pratensis shows extremely high raF values under alkaline conditions, though on this experimental field it grows excellently with a $\mathrm{pH}$ $\mathrm{KCl}=3.8$. In the completely fertilized ( $\mathrm{N}$ as $\mathrm{SA}$ ) parts of the Rothamsted plots (Williams, 1978) which were limed after $1903, H$. lanatus was rapidly replaced by $A$. pratensis, but in contrast $A$. pratensis on the unlimed part persisted a very long time (upwards 50 years!) before it was suppressed by $H$. lanatus (Table 7).

In Newcastle (Arnold et al., 1976) $A$. pratensis still dominated the unfertilized treatment with $\mathrm{pH}-\mathrm{CaCl}_{2} 4.1$ after 80 years.

Dactylis glomerata. D. glomerata showed remarkably few fluctuations from year to year; for 20 years its F\% in the 0 pasture plots was 10 , whereas it was found in the

Table 7. Changes in the DW percentages with time of 2 species on the $\mathrm{N}_{3} \mathrm{PK}$-unlimed treatment (plot $11^{1}$ ). This plot received nitrogen as ammonium sulphate (Williams, 1978).

\begin{tabular}{lrrrrrrrrrrr}
\hline & 1858 & 1862 & 1867 & 1872 & 1877 & 1903 & 1914 & 1919 & 1947 & 1949 & 1973 \\
$\begin{array}{l}\text { Alopecurus pratensis } \\
\text { Holcus lanatus }\end{array}$ & - & 3 & 13 & 12 & 10 & 28 & 1 & 1 & 1 & $\mathrm{t}$ & - \\
\hline
\end{tabular}


sample of one of the 0 hay plots only this last year, the species rose to an F\% of about 40 in the other 0 hay plot.

This species increased in all the hay plots, but by far the most in the PK plots (dominant species), whereas it persisted with low F\%s in all the pasture plots. Why $D$. glomerata did not dominate in the NPK hay plots and even is already decreasing (Fig. 2) is explained by the explosive development of $A$. pratensis at the beginning of the experiment and the increase in A. elatius (and E. repens) or A. sylvestris after 20 years.

This is a another good example of what the separation of environmental factors may reveal. $D$. glomerata evidently grows well under good PK and hayfield conditions. Since this combination seldom occurs in our cultivated grasslands, the raF values of Kruijne et al. (1967) do not indicate a preference for hayfield conditions. Kruijne et al. did find an extremely high raF value for response to alkaline conditions, whereas $D$. glomerata sharply increased in the $\mathrm{PK}$ plots with the low $\mathrm{pH}-\mathrm{KCl}$ of 3.8 (Table 1). The high raF value is probably related to the associated factors alkaline-hayed-dike slopes with an Arrhenatheretum, well represented in the relevant material.

In Rothamsted (Williams, 1978) D. glomerata generally developed better on the limed parts than on the unlimed parts, provided that $\mathrm{N}$ and $\mathrm{K}$ had also been applied, which agrees with Arnold et al. (1976).

Poa pratensis. In common with $D$. glomerata this species fluctuates only slightly. For instance, $P$. pratensis can persist in the 0 treatment with an $\mathrm{F} \%$ of about 4 for 20 years, but also with an $\mathrm{F} \%$ of about 45 , depending on the $\mathrm{F} \%$ at the beginning of the experiment.

In this experimental field $P$. pratensis only responded highly in the hay plots with liming and NPK fertilizer, although in the latter treatments its F\% dropped sharply after about 9 years (Fig. 2), probably because of the competition of $D$. glomerata. In the pasture plots this species remained unimportant, although it developed well in the PK and NPK treatments.

Kruijne et al. (1967) considered $P$. pratensis to be a pasture species rather than a hayfield species, which probably is caused by the association hayfield-poor conditions (see also under Dactylis glomerata).

In Rothamsted (Williams, 1978) $P$. pratensis as $D$. glomerata generally performed better on limed parts than on the unlimed parts, provided that for $P$. pratensis at least $\mathrm{N}$ and $\mathrm{P}$ were supplied.

Lolium perenne. This is a pronounced pasture species, which rapidly dropped in the hay plots and has almost disappeared. In the fertilized and limed pasture plots it spreads rapidly, whereas it persisted at a consistent level in the unfertilized pasture plots.

According to the raF values of Kruijne et al. (1967) this is a species that occurs especially in the pure pastures under high fertility conditions.

Poa trivialis. P. trivialis is known as a moisture indicator and because of the im- 
proved drainage conditions it decreased throughout the plots, except for the $\mathrm{Ca}$ plots and the NPK pasture plots, where it spread widely or persisted, respectively. This great response to liming could be related to an improved structure of this heavy clay soil and thus with an improved moisture retaining capacity. In the literature there is evidence that $P$. trivialis responds favourably to liming (Grundler \& Voigtländer, 1979), although in Rothamsted (Williams, 1978) it only persisted well with a complete fertilizing of nitrate nitrogen or farmyard manure (FYM) + lime.

Its frequency may fluctuate widely; in the extremely dry year 1976 the species distinctly decreased in all the plots, with a rapid recovery on some of the plots.

Arrhenatherum elatius. This pronounced hayfield species after some 10 years showed explosive development in one of the replicates of the NPK and Ca hay plots, whereas in the other $\mathrm{Ca}$ hay plot and the $\mathrm{P}$ and $\mathrm{PK}$ plots it has increased only in the last few years. Since $A$. elatius developed well in an NPK plot with a $\mathrm{pH}-\mathrm{KCl}$ of 3.8, it seems that a high $\mathrm{pH}$ value is not necessary for this species, in contrast with the suggestions of Kruijne et al. (1967).

In Rothamsted (Williams, 1978) A. elatius could persist on the unlimed parts of the NPK plots with a $\mathrm{pH}-\mathrm{KCl}$ of 3.7 with a high weight percentage for 60 years, but was finally suppressed by $H$. lanatus, whereas on the limed NPK plots $A$. elatius dominated alternately with Alopecurus pratensis. In the limed part of the NPK plot fertilized with sodium nitrate, $A$. elatius even dominated consistently.

Trisetum flavescens. T. flavescens is only mentioned, here, because this species, which decreased on all the plots through the years, showed a remarkable comeback in the P and Ca hay plots in the last years (Fig. 5). Hence, in Rothamsted (Williams, 1978) it was striking that, except in the FYM plots, $T$. flavescens temporarily occurred most frequently in the limed part of the $\mathrm{P}(\mathrm{Na}, \mathrm{Mg})$ plot (plot 8).
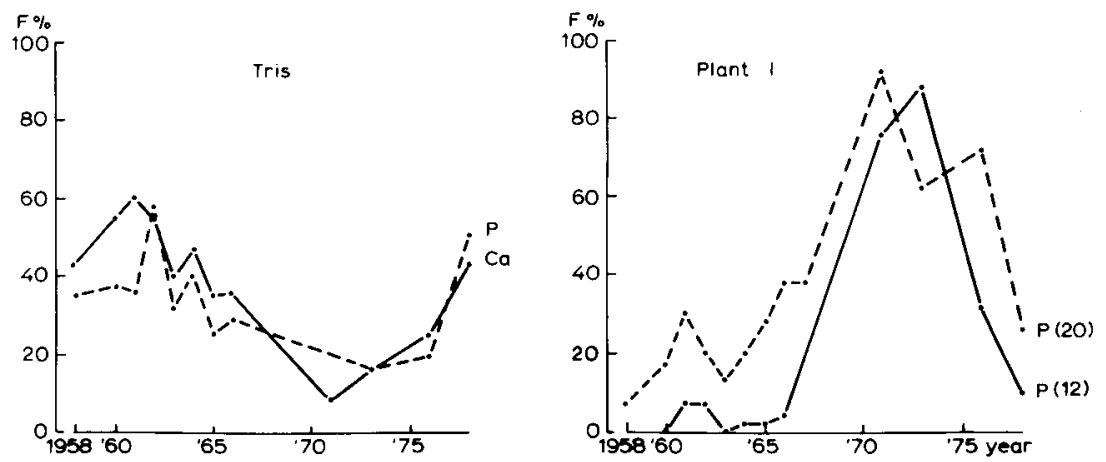

Fig. 5. The frequency percentages (average of the replicates) of Trisetum flavescens (Tris) and Plantago lanceolata (Plant l) against time. Plots are indicated by letter symbols (fertilizer treatments) and ciphers (plot number). 
Centaurea pratensis. As in Rothamsted (Williams, 1978) C. pratensis is persistent, except for the plots fertilized with NPK. Its F\% is higher in the hay plots than in the pasture plots (Table 5). According to Kruijne et al. (1967) this is a typical species of hayfields and poor conditions.

Plantago lanceolata. This species shows in all the hay plots (except for the NPK treatments, where it had disappeared already after a few years) a typical rise-andfall behaviour (Fig. 5), which cannot yet be explained from the observations. This behaviour is most distinct in the $P$ plots.

According to Kruijne et al. (1967) this is also a typical hayfield species indicating poverty, but in the unfertilized pasture plots the species persisted even if the F\% was low.

In Rothamsted (Williams, 1978) $P$. lanceolata also showed a rise-and-fall behaviour, especially on the unlimed parts $(\mathrm{pH}-\mathrm{KCl} 5.2)$ of the $0, \mathrm{P}$ and sodium nitrate plots. In our experimental field $P$. lanceolata developed well with $\mathrm{pH}-\mathrm{KCl}$ values of 4.0 and 6.5 (Table 1). Probably the high raF value at alkeline response (Kruijne et al., 1967) is related to alkeline dike slopes with an Arrhenatheretum, which are hayed (see Dactylis glomerata).

Chrysanthemum leucanthemum. According to Kruijne et al. (1967) this is a typical hayfield species indicating poor conditions and indeed the species disappeared rapidly from all the NPK plots, whereas it persisted on the unfertilized pasture plots. Contrary to the high raF value for alkaline response, $C$. leucanthemum performs no better on the limed hay plots than on the other hay plots (except for the NPK treatments), although the species recovered distinctly in the last few years.

Ranunculus acris. The F\%s of this species show a distinct, though irregular periodicity (Fig. 6). After 18 years the species seemed to disappear finally, but in the last 3 years a remarkable recovery occurred in most of the hay plots. The highest
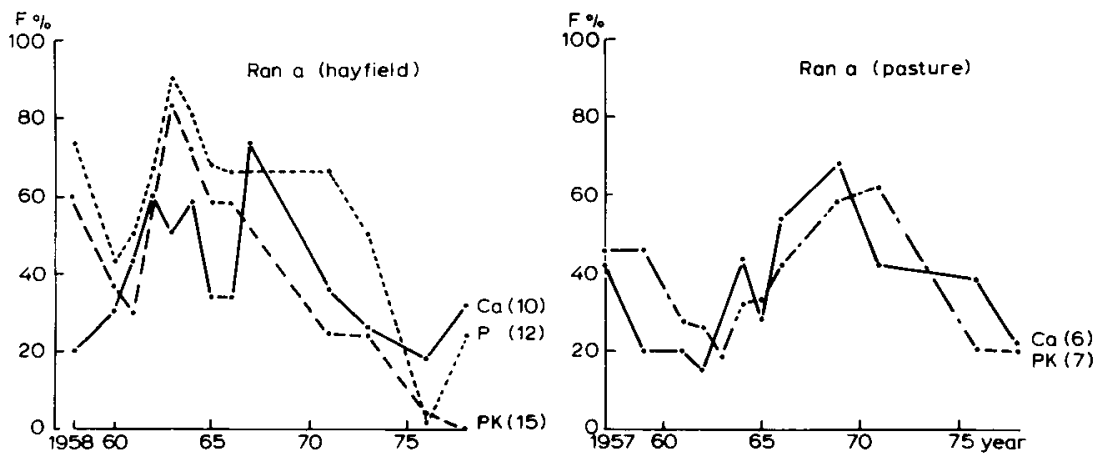

Fig. 6. Frequency percentages of Ranunculus acris (Ran a) on some hay (left) and some pasture (right) plots. 
F\%s were found on the P plots, but in the last few years those in the Ca plots were higher. In NPK hay plots the species almost disappeared within 10 years. The species is frequent in both the hay and the pasture plots, however its $\mathrm{F} \%$ in the pasture plots also declined with an NPK dressing.

In Rothamsted (Williams, 1978) the highest weight percentages of $R$. acris were found on the plots fertilized with phosphate only (or plus $\mathrm{Na}, \mathrm{Mg}$ ), independent of liming or not.

According to Kruijne et al. (1967) $R$. acris is a species that does not indicate an extreme condition for any environmental factor.

Ranunculus repens. This species like $R$. acris shows irregular periodicity, but is not distinctly affected either by use or fertilizing (except for the NPK hay plots, where it has disappeared). The high F\%s in the pasture plots and in Table 5 do not agree with the general picture of 20 years of observation.

Rumex acetosa. R. acetosa also fluctuates somewhat (though less than Ranunculus acris), its lowest F\% occurred in 1976, after which it recovered rapidly, excluding the NPK hay plots where it almost disappeared after 18 years. In the pasture plots it persisted well, except for the Ca treatment and the NPK plots.

In Rothamsted (Williams, 1978) $R$. acetosa persisted with low weight percentages in nearly all the treatments, but sometimes attained high percentages $(>20)$ in the $\mathrm{N}_{2} \mathrm{~K}(\mathrm{Na}, \mathrm{Mg})$ plot. The response of $R$. acetosa to liming was neither distinct in Rothamsted.

Achillea ptarmica. This species shows distinct rise-and-fall curves for some adjacent plots, independent of fertilizing. Fig. 7 shows three examples. A. ptarmica attained its maximum after 10 to 13 years, excluding the NPK plot, where after 7 years the population collapsed within one year, probably because of the competition by Alopecurus pratensis, $P$. pratensis and D. glomerata.

A. ptarmica according to Kruijne et al. (1967) is a typical hayfield species indicat-
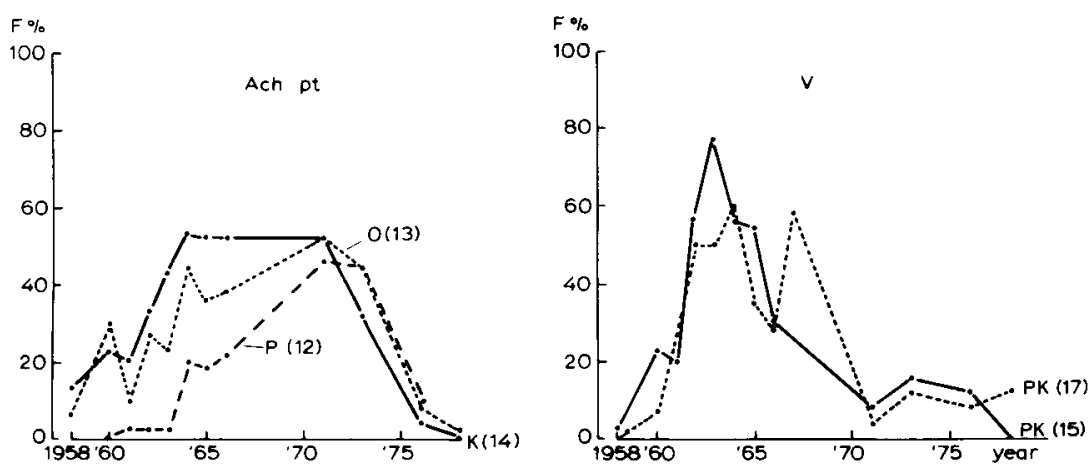

Fig. 7. Frequency percentages of Achillea ptarmica (Ach pt) and Vicia cracca (V) on some hay plots against time. Plots are indicated by letter symbols (fertilizer treatment) and ciphers (plot number).

Neth. J. agric. Sci. 31 (1983) 
ing poor conditions. The results of this field experiment show that it is a dynamic species, which also persisted in the unfertilized pasture plot for 20 years, though with very low F\%s.

Achillea millefolium. A. millefolium attained F\%s of about 40 only in the PK hay plots, after which it declined again. Striking is that in Rothamsted (Williams, 1978) this species occurred most frequently on the unlimed PK plots. Hence, it is not a species of extremely poor conditions and it is reasonably persistent in the pasture and hay plots.

Anthriscus sylvestris. This robust, tall-growing species spread considerably in only one of the NPK hay plots in the last 10 years (Fig. 2). In Rothamsted (Williams, 1978) and Newcastle (Arnold et al., 1976) it only occurred in the plots fertilized with $\mathrm{NaNO}_{3}+\mathrm{P}+\mathrm{K}$ or with farmyard manure, so also in the more fertile plots.

For the $\mathrm{pH}$ value according to Kruijne et al. A. sylvestris indicates alkaline conditions, which does not agree with a $\mathrm{pH}-\mathrm{KCl}$ of 3.8 in our plot. In Rothamsted (Williams, 1978), however, A. sylvestris did not occur in the treatments fertilized with $\mathrm{NH}_{4}-\mathrm{N}$ with $\mathrm{pH}$ values lower than about 5.0.

Taraxacum Sect. Vulgaria. After a period of increase in the beginning of the 1960s, Taraxacum decreased to very low $\mathrm{F} \% \mathrm{~s}$, especially in the hay plots. In the Ca pasture plot it persisted with the average highest $\mathrm{F} \%$.

This agrees with the results of Rothamsted where Taraxacum occurred generally more frequently in the limed parts than in the unlimed parts, especially combined with PK or NPK fertilizer.

According to Kruijne et al. (1967), Taraxacum is a species with a wide ecological amplitude.

Legumes. Except for $T$. repens, the leguminous species prefer the hay plots. In general these species show a rise-and-fall curve, independent of the fertilizer treatment. Fig. 7 shows an example of Vicia cracca in both the PK hay plots. Almost the same applies to Lathyrus pratensis. In the Rothamsted (Williams, 1978) experiment the latter species responded distinctly in the PK plots with widely fluctuating dry weight percentages from year to year.

Trifolium pratense is still present with only low $\mathrm{F} \%$ s throughout the experimental field, it persisted longest in the PK hay and pasture plots, independent of liming. This does not agree with Kruijne et al. (1967), who consider it a distinct hayfield species occurring especially at high pH values. In Rothamsted (Willams, 1978) it neither responded to liming, but it did to $\mathrm{PK}$ and $\mathrm{P}$ only.

\section{Discussion and conclusions}

In long-term studies about the effect of management measures on the botanical composition of grassland, we are always confronted by the observation that, because of the time factor, the initial situation of the control plot changes. Moreover 
in this experiment the original use, alternate pasture was changed in grazing only or haying only. As the most suitable plot to study the time factor we have chosen the unfertilized pasture plot, because this plot showed the least changes for both soil fertility and botanical composition.

Because the drainage conditions in the area where the experimental fields are situated were improved, a number of species indicating wet conditions have more or less sharply decreased, such as Agrostis canina, Poa trivialis, Festuca pratensis, Carex nigra, Carex panicea, Achillea ptarmica, Cardamine pratensis, Cirsium palustre and Lysimachia nummularia. The behaviour of $C$. palustre is interesting, because this biennial species was not found in any of 360 samples of the hay plots when sampled for the first time in 1958. Countings in 1965 and 1966, and botanical observations in 1969 showed that $C$. palustre occurred frequently in the lower parts of the experimental field (Nijland \& Wind, 1970). Then, a sharp decrease occurred and after 1977 the species was no longer found in the samples. Perhaps the drier environmental conditions were limiting germination of $C$. palustre. A. ptarmica also spread in the first years of the experiment with its rhizomes seeming to infest the lower-situated plots, but after 1970 the F\% of this species also decreased (Fig. 7).

Distinct exceptions to the decline in moisture indicators are Deschampsia cespito$s a$ in the pasture plots, Carex acuta in the hay plots and the high F\%s of P. trivialis in the Ca plots at both types of use, while Trisetum flavescens and Luzula campestris, indicating drought according to Kruijne et al. (1967), decreased distinctly. The increase of $P$. trivialis may be caused by deeper rooting of this grass species brought on by liming. This may also be a result of the improved structure of this heavy clay soil. At the same time, nitrogen may be released by mineralization caused by liming of the soil and the roots will seem to grow towards this nitrogen source. The low $\mathrm{pH}$ value $(\mathrm{pH}-\mathrm{KCl}<4.0)$ of the soil of the other hay plots may also have limited the development of the grass roots. The findings of Wind (1967) showed that the roots of oats and wheat do not grow into soil layers with $\mathrm{pH}-\mathrm{KCl}<3.5$. Striking is that for such a long period still reasonable grass yields were obtained on the NPK hay plots at low $\mathrm{pH}$ values. Perhaps there are differences in the responses of grass species to the $\mathrm{pH}$ value of the soil, with respect to their roots. C. pratensis also persisted well in the hay plots with liming.

Next we want to consider the influence of the separate plant nutrients on the botanical composition of the hay and pasture plots. In the past 20 years great amounts of minerals were removed with the herbage from the unfertilized hay plot, which did not show in the soil analysis for the $\mathrm{P}$ content, though the $\mathrm{K}$ content showed some decrease. The number of plant species in the unfertilized hay plot declined by $25 \%$ in the period 1958-1978, which is also apparent from the decrease in the average number of plant species per sample from 8.5 to 5.2 per $25 \mathrm{~cm}^{2}$. Perhaps this was caused by changing the type of use from alternate pasture to haying only. The aspect of the vegetation, however, did not change and Agrostis spp., Anthoxanthum odoratum, Festuca rubra and to a less extent Alopecurus pratensis continued to be the most important plant species. Almost the same applies to the $\mathrm{K}$ hay plot. The extremely high $\mathrm{K}$ content in the soil did not cause changes in the botanical composition of the hay plots. 
Fertilizing with phosphate only neither caused great changes in the botanical composition of the hay plots. Striking are, however, the higher F\%s of Holcus lanatus in the P hay (PK-hay) plots. This result agrees with the behaviour of this species in the Park Grass Plots (Williams, 1978). Here $H$. lanatus has dominated the grass vegetation already for 70 years, also at a low $\mathrm{pH}$ value caused by prolonged dressings of ammonium sulphate, and a sufficient PK status of the soil. The other changes in the botanical composition of the P plot compared to that of the unfertilized plot agree with the $14 \%$ yield increase, which means a slight increase in the tall-growing grasses $A$. pratensis, Arrhenatherum elatius and Dactylis glomerata. Our results do not agree with the findings of Ellenberg (1952), who distinguished groups of plant species by their prevailing occurrence on K-poor and K-rich, or Ppoor and P-rich soils, respectively.

The botanical composition of the Ca plots show some notable changes. Both in the hay and in the pasture plots the F\%s of Agrostis spp., A. odoratum, F. rubra and $H$. lanatus decreased sharply, sometimes the relevant species was no longer present in the sample (Table 5). In the hay plots, however, species as $A$. pratensis, A. elatius, D. glomerata and Poa pratensis increased considerably and in the pasture plots also $A$. pratensis, further Lolium perenne and Phleum pratense. These results correspond well with those of the correlative-ecological study of de Vries (Kruijne et al., 1967), in which decreased and increased grass species frequently occurred on soils with a low and high $\mathrm{pH}$ value, respectively. $F$. rubra is an exception, in that research this species indicates a somewhat higher $\mathrm{pH}$ value. Still, in our field experiment mainly the tufty species $F$. rubra var. commutata occurred. The changes in the botanical composition of the sward with liming are also mentioned by other authors. In the PK and NPK plots, however, the increased grass species were found to grow excellently also at a low $\mathrm{pH}$ value, therefore the so-called effect of liming is perhaps mainly caused by mineralization of the soil nitrogen.

The combined $\mathrm{P}$ and $\mathrm{K}$ application on the hay and pasture plots increased the dry matter yield compared with the unfertilized plot with a mean of 0.9 and $1.3 \mathrm{t}$ per ha per year, respectively. The yield increase of the hay plots compared with that of the P plot was only $0.2 \mathrm{t}$ per ha per year. Roughly, the botanical composition of the PK plots was in between that of the unfertilized and the Ca plots. Some less productive species such as Agrostis spp. and $A$. odoratum decreased somewhat, whereas the more productive species such as $A$. pratensis, $D$. glomerata and $L$. perenne increased. The increase in both last species was limited to one type of use, that is the hay and the pasture plots, respectively. The increase in legumes to be expected with PK fertilizing occurred especially at the beginning of this field experiment. For instance, the weight percentage of the legumes in the hay plot No 17 in 1966 and 1968 was 13 and 15, respectively, with Vicia cracca and Trifolium pratense as the most important components. After 1968 the weight percentage decreased, perhaps because of diseases and pests (see also Fig. 7). With grazing the PK dressing stimulated white clover (Table 4 ) and also because of this better $\mathbf{N}$ supply L. perenne increased sharply.

The NPK dressing caused great changes in the botanical composition of the sward with both types of use. Although the dressings on the hay plots were much 
higher than those on the pasture plots, the important differences in the botanical composition of these plots were caused rather by the type of use than by the difference in the amount of fertilizer. In the experimental period the number of plant species in the samples of the hay plots decreased much more than in those of the pasture plots. This is also shown by the average number of plant species per boring of $25 \mathrm{~cm}^{2}$, which was 2.0 and 5.9 , respectively. In the hay plots the early-flowering grass species $A$. pratensis soon began to dominate, so that the low-growing grasses as Agrostis spp., A. odoratum, F. rubra and $H$. lanatus and most of the broadleaved herbs were suppressed because of light deficiency.

In both replicates the botanical composition of the sward showed almost the same changes in the course of years, that is a subsequent increase and decrease in the frequency percentages of $A$. pratensis, $P$. pratensis and $D$. glomerata, followed by an increase of $A$. elatius (Fig. 2). After 1966 Elytrigia repens in plot 11 and Anthriscus sylvestris in plot 19 started spreading.

On the pasture plots the increased yield from fertilizing increased the number of cattle grazing days, which caused a more frequent defoliation of the grass crop, more manure and urine patches and increased damage by treading. Because of this $L$. perenne spread widely and the less productive species and broad-leaved herbs were suppressed. $H$. lanatus persisted well with the increased fertilizer application. The higher percentages of E. repens, Poa annua and Stellaria media are interesting (Table 5). Under modern grassland exploitation these plant species often occur in our perennial ryegrass pastures. Similar as in the PK and Ca pasture plots Trifolium repens occurred often in this plot. Detailed observations on the pasture plots showed that the aggregation of $T$. repens increased at higher fertilizer dressings (Dirven et al., 1971).

The preceding shows that the influence of fertilizers on the botanical composition of the sward is closely related to the use of the herbage produced. By calculating the relative preference for use the behaviour of the plant species under various types is illustrated. The relative preference of a species is the pasture/hayfield ratio of the mean frequency percentages in the $0, \mathrm{PK}, \mathrm{Ca}$ and NPK plots in 1978 divided by the pasture/hayfield ratio of the mean frequency percentages in the same plots in the initial situation. Fig. 8 shows the relationship between the relative preference for use and indication values of Kruijne et al. (1967). The results are in good agreement with the correlative ecological study (Kruijne et al., 1967). There are some exceptions: $H$. lanatus, D. cespitosa, E. repens, Galium verum and $P$. pratensis. The higher frequency of $D$. cespitosa, $H$. lanatus and $E$. repens in the pasture plots is mainly caused by their low palatability, so that they are hardly grazed. In the hay plots the frequency percentages of $H$. lanatus decreased considerably after a late frost in 1962, this decrease continued through the winter 1962/1963. No distinct recovery occurred in these plots, afterwards. In the pasture plots the frequency percentages of this species remaind at a level of 50-60 in 1962, decreased to 30 in the spring of 1963, but recovered to the original level in 1965. Perhaps this grass species is better protected from frost damage at undisturbed growth (in the pasture plots).

Despite Kruijne et al. (1967) considering Agrostis canina, A. odoratum, H. lanatus, Centaurea pratensis, Leontodon taraxacoides, Plantago lanceolata and Chrys- 


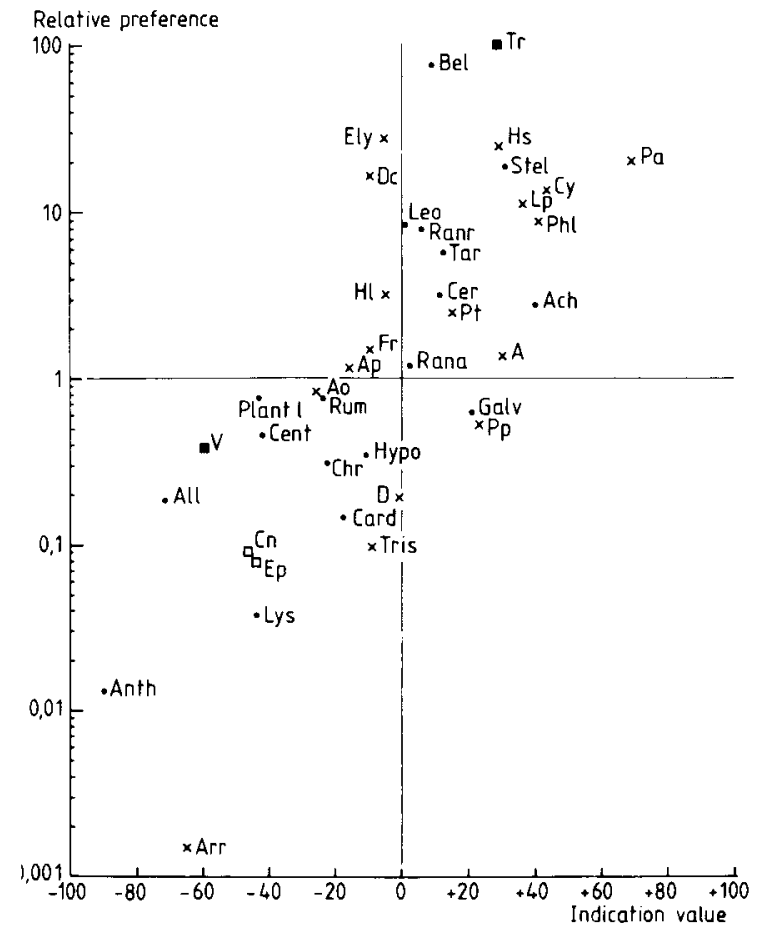

Fig. 8. Relationship between the relative preference of some grassland species for grazing or haying (see text) and the indication values for type of use (Kruijne et al., 1967).

$\mathrm{A}=$ Agrostis tenuis + A. stolonifera, Ach $=$ Achillea millefolium, All $=$ Allium vineale, Anth $=$ Anthriscus sylvestris, Ap $=$ Alopecurus pratensis, Ao $=$ Anthoxanthum odoratum, Arr = Arrhenatherum elatius, Bel = Bellis perennis, Card $=$ Cardamine pratensis, $\mathrm{Cn}=$ Carex nigra, $\mathrm{Cent}$ $=$ Centaurea pratensis, $\mathrm{Cer}=$ Cerastium fontanum, $\mathrm{Chr}=$ Chrysanthemum leucanthemum, $\mathrm{Cy}=$ Cynosurus cristatus, $\mathrm{D}=$ Dactylis glomerata, Dc = Deschampsia cespitosa, Ely $=$ Elytrigia repens, $\mathrm{Ep}=$ Equisetum palustre, $\mathrm{Fr}=$ Festuca rubra, Gal $\mathrm{v}=$ Galium verum, $\mathrm{HI}=$ Holcus lanatus, $\mathrm{Hs}=$ Hordeum secalinum, Hypo = Hypochaeris radicata, Leo $=$ Leontodon autumnalis, $\mathrm{Lp}=$ Lolium perenne, $\mathrm{Lys}=$ Lysimachia nummularia, $\mathrm{Phl}=$ Phleum pratense, Plant $\mathrm{l}=$ Plantago lanceolata, $\mathrm{Pa}$ $=$ Poa annua, $\mathrm{Pp}=$ Poa pratensis, $\mathrm{Pt}=$ Poa trivialis, $\mathrm{Ran}$ a $=$ Ranunculus acris, $\operatorname{Ran} \mathbf{r}=$ Ranunculus repens, $\operatorname{Rum}=R u$ mex acetosa, Stel $=$ Stellaria media, Tar $=$ Taraxacum Sect. Vulgaria, $\mathrm{Tr}=$ Trifolium repens, Tris $=$ Trisetum flavescens and $\mathrm{V}=$ Vicia cracca. $\mathrm{x}=$ grasses, $\mathbf{=}=$ legumes, $\square=$ grasslike weeds, $\bullet=$ herbs.

anthemum leucanthemum typical hayfield species, they persisted reasonably well in the 0 pasture plots (Table 5). Therefore, these species primarily indicate soil poverty and not hayfield use. However, species as, for instance, Agrostis spp., P. pratensis, and A. ptarmica, which Kruijne et al. (1967) do not consider to be hayfield species at all, persisted excellently or even increased in the hay plots.

The frequency percentages of some plant species decreased with both types of use, namely Cynosurus cristatus, L. campestris, Ranunculus acris and Stellaria graminea. We do not know exactly why, but perhaps, this was caused by changing from alternate pasture to grazing only and cutting twice a year. The F\% of $A$. pratensis increased with both haying and grazing, although this is a hayfield species according to Kruijne et al. (1967).

Besides the grassland species that disappear from or permanently establish in a sward, there is a group of plant species, of which the frequency percentages rise and fall during shorter or longer periods. In our experiments these were $A$. odoratum, $P$. pratensis, $T$. flavescens, $P$. lanceolata, $R$. acris, Rumex acetosa and $V$. cracca. Legumes may show such rise-and-fall behaviour, after spreading of the species the incidence of diseases and pests also increase, and so the plant species will disappear 
from the sward after some time. These cyclic processes, however, will usually occur in the hay plots, especially with plant species of limited longevity. A good example are the rise-and-fall curves of $P$. lanceolata in the $P$ hay plots (Fig. 5). The findings of Sagar (1970) in a population of $P$. lanceolata showed that within 2 years $65 \%$ of the original number of plants died. Recovery of this population is only possible by generative reproduction, that is by the formation of viable seed and re-establishment in the sward. Variation in the date of the first cut in our research, between 14 June and 15 July with the accompanying changing weather conditions, may have stimulated, or not, the formation of viable seed, while establishment of the plant species was also dependent on the variation of these factors. A better understanding of these processes enables better management of the changes in the botanical composition of the sward.

Lastly, we want to point out the sometimes contradictory findings in the correlative, ecological study and our field experiments. For instance, the relation between the acidicity of the soil and the occurrence of particular plant species.

According to Kruijne et al. (1967) the following plant species increasingly indicate a high $\mathrm{pH}$ value, $F$. rubra, $P$. lanceolata, $A$. pratensis, $C$. leucanthemum, $T$. pratense, E. repens, $T$. flavescens, $D$. glomerata, $A$. elatius and Anthriscus sylvestris. However, these plant species in our field experiments occurred more or less frequently at a low $\mathrm{pH}$ value ( $\mathrm{pH}-\mathrm{KCl}$ even below 4.0). Since the environmental factors in the correlative, ecological study were associated, we have to conclude that other factors than the $\mathrm{pH}$ value determine the occurrence of these plant species. For $E$. repens and $A$. sylvestris these other factors are an NPK dressing.

Recapitulating we may conclude that the effect of applying single plant nutrients on the botanical composition of the sward is small; perhaps Ca is an exception. However, when the grassland yield increases because of the combined application of certain fertilizers, considerable changes may occur in the sward depending on the type of use.

\section{Acknowledgement}

The authors are greatly indebted to Prof. Ir M. L. 't Hart and the late Prof. Dr D. M. de Vries for their valuable advice and their continuous interest in the experiment.

\section{References}

Arnold, P. W., F. Hunter \& P. Gonzales Fernandez, 1976. Long-term grassland experiments at Cockle Park. Annls agron. 27 (5-6) 1027-1042.

Bergh, J. P. van den, 1979. Changes in the composition of mixed populations of grassland species. In: M. J. A. Werger (Ed.), The study of vegetation. Junk, The Hague, p. 59-80.

Boer, Th. A. de, 1956. Graslandvegetatiekartering. Landbouwvoorlichting 13.11: 623-626. (Dutch.)

Bosch, S., 1956. The determination of pasture yield. Neth. J. agric. Sci. 4: 305-313.

Dirven, J. G. P., G. O. Nijland \& K. Wind, 1971. Aggregation of Trifolium repens at various fertilizations. Acta bot. neerl. 20(3) 370-378. 
Elberse, W. Th., 1966. Invloed van gebruik en bemesting op botanische samenstelling en produktie van verwaarloosd grasland. Versl. Inst. biol. scheik. Onderz. LandbGewassen No 40. (Dutch.)

Ellenberg, H., 1952. Wiesen und Weiden. Verlag Eugen Ulmer, Stuttgart.

Grundler, Th. \& G. Voigtländer, 1979. Die wirkung langjähriger Kalkung bei physiologisch alkalischer und saurer NPK Düngung auf Futter Qualität und Heuertrag einer Feuchtwiese. Bayer. landw. Jahrb. 3: 337-350. (German.)

Jagtenberg. W. D. \& Th. A. de Boer, 1958. De invloed van graskooien op de grasopbrengst. Landbouwk. Tijdschr. 70: 879-889. (Dutch.)

Kruijne, A. A., D. M. de Vries \& H. Mooi, 1967. Bijdrage tot de oecologie van de Nederlandse graslandplanten. Versl. landbouwk. Onderz. 696: 1-65. (Dutch: English summary.)

Mannetje, L. 't \& K. P. Haydock, 1963. The dry-weight-rank method for the botanical analysis of pasture. J. Brit. Grassld Soc. 18(4) 268-275.

Nijland, G. O. \& K. Wind, 1970. Bijdrage tot de oecologie van Cirsium palustre (L.) Scop. Gestencilde Mededeling, Landbouwhogeschool Wageningen No 20. (Dutch.)

Sagar, G. R., 1970. Factors controlling the size of plant populations. Proc. 10th Br. Weed Control Conf. 3: $965-979$.

Vries. D. M. de, 1937. Methods of determining the botanical composition of hayfields and pastures. Rep. 4th int. Grassld Congr. (Great Britain): 474-480.

Vries, D. M. de, 1949. Survey of methods of botanical analysis of grasslands. Rep. 5th int. Grassld Congr. (Netherlands): 143-153.

Watt, A. S., 1960. Population changes in acidiphitous grass-heath in Breckland, 1936-57. J. Ecol. 48: 605-629

Watt. A. S., 1971. Factors controlling the floristic composition of some plant communities in Breckland. In: E. Duffey \& A. S. Watt (Eds.), The scientific management of animal and plant communities for conservation. Proc. 11th Brit. Ecol. Soc. Symp.: 137-152. Blackwell, Oxford.

Williams, E. D., 1978. Botanical composition of the Park Grass Plots at Rothamsted, 1856-1976. Rothamsted Experimental Station, Harpenden, 1-61.

Wind, G. P., 1966. Regen. Landbouwk. Tijdschr. 78(11) 365. (Dutch.)

Zijlstra, K., 1937. Het bepalen van de botanische samenstelling van het grasland en de betekenis daarvan voor de praktijk. Landbouwk. Tijdschr. 49: 141-154. (Dutch.) 